\title{
THE BENEFITS OF INDICATION OF SOURCE PROTECTION ON IKAT NATURAL DYEING FOR SMALL-SIZED ENTERPRISES IN SUMBA
}

\author{
Helitha Novianty Muchtar \\ Lecture in Departemen Economic, Faculty of Law \\ Padjadjaran University \\ Bandung, Indonesia \\ Helitha.novianty@unpad.ac.id
}

Ahmad M. Ramli

Professor in Departemen of Technology Information Faculty of Law, Padjadjaran University

Padjadjaran University

Bandung, Indonesia

\author{
Muhamad amirulloh \\ Lecture in Departemen of Technology Information \\ Faculty of Law, Padjadjaran University \\ Bandung, Indonesia \\ muhamad.amirulloh@unpad.ac.id
}

\begin{abstract}
Ikat from Sumba owns ornamental and typical background of ancient culture which is considered to be sacred according to local norms, customs, and beliefs. Its patterns symbolized daily activities within the society are made through a binding process called Ikat Sumba. Ikat is originally from Sumba, indigenous people and local society wear Ikat for ceremonial occasion or daily basis. The process of making Ikat is exceptionally traditional. The process of Ikat dyeing itself is highly sacred, starting from gathering the natural ingredients.
\end{abstract}

Indication of source is part of intellectual property rights, the indication of source in terms of information regarding the origin of certain products and the location of the materials used, is the consumers' guidance on the quality of products, in this case Ikat. Sumba refers to the island of Sumba, East Nusa Tenggara. Ikat Sumba has good quality and undergoes natural dyeing process. Protection for indication of source becomes a solution in order to improve small-sized enterprises in Sumba.

Keywords: Indication of source, natural dyeing, Ikat Sumba

\section{INTRODUCTION (HEADING 1)}

Indication of source is part of intellectual property protection. It signifies the origin of the materials used for certain products. Protection for indication of source by local government is an important strategy in improving local economical climate by small and medium-sized enterprises.
Indication of source is a means of protecting smallsized enterprises from unfair business competition. Ikat Sumba is a typical textile in the island of Sumba. Each place, from East Sumba to Southwest Sumba, creates different pattern of Ikat. In the process of dyeing the textile, natural ingredients are gathered from forest, mangroves, and plantation in the surrounding area where the production of Ikat takes place.

Communities in East Sumba have long been making, wearing, and merchandising the textile, known as Hinggi, traditional clothing for male in rectangle form. Traditional clothing for female is known as Lawu or sarong, while scarves are worn by both male and female on their shoulders. Weaving process is manually and traditionally performed by women.

Ikat is named as such due to the fact that prior to the dyeing process, the textile is tied using raffia rope, then the textile is dyed in natural textile coloring. The tied area remains white and the other area becomes the same color as the natural textile coloring.[1]

The business of Ikat in Sumba is in the form of home-based small-sized enterprises, most of which are either 
individually and family business, from weaving to the dyeing process. The commodity produced remains in limited number.

The making of Ikat Sumba uses natural dye taken from natural sources, for example leaves, roots, and barks. Natural dyeing produces better result than synthetic dyeing. Also, natural dyeing strengthens the textile and prevents it from damage even after being stored for decades; hence, natural dyeing is highly demanded by many.

Until present, the natural dyeing of Ikat Sumba has not been acknowledged as a geographical indication or indication of source from the island of Sumba. Based on the above description, it is considered to be necessary to conduct a benefit-related analysis regarding protection of indication of source for natural dyed Ikat.

\section{PREVENTION OF UNFAIR COMPETITION THROUGH PROTECTION OF INDICATION OF SOURCE}

\section{A. FRAUD IN TERMS OF INDICATION OF SOURCE}

Intellectual property is inseparable from the law of intellectual property; one of which is international agreement related to Geographical Indication. Madrid Agreement 1891 on the Repression of False or Deceptive Indications of Course on Goods and Madrid Protocol 1989 concerning the International Registration of Marks are two international agreements which are related to Geographical Indication.[2] Both agreements are usually generalized as Madrid Agreement 1891. As a matter of fact, one agreement regulates the aspect of marks, while the other regulates the aspect of indication of source.

Paris Convention uses the term "Indications of Source" and "Appellation of Origins" for Geographical

Indication objects in broad context.[3] The convention guarantees the protection of indication of source by ordering the seizure of imported products using geographical indication of source or indication of misleading source of producer, both in direct and indirect manner.

The convention regulates the overcoming of unfair business competition. It requires its state members to seek effective protection for producers so that fraud practices are avoidable. Fraud in terms of indication of source is most likely to occur, namely between Ikat Jepara and Ikat Sumba; both own similar patterns and coloring, but different stitches. More often than not, producers mislead its consumer to think Ikat Jepara as Ikat Sumba due to the fact that Ikat Sumba is more popular. Such practice constitutes fraud as part of unfair competition.

Fraud to the extent of geographical indication occurs if the producers intentionally mislead its consumers to perceive certain product, label, or brand as another product which is well-acknowledged in terms of quality. The practice is normally in the form of oral by saying that a product comes from particular region or by embedding a label on the product.

\section{B. PROTECTION OF INDICATION OF SOURCE}

A region becomes an important aspect in the trade of goods and services. It is a means of identifying the quality of a product based on origin. The region identifies the quality of a product, for example sweet potato from Cilembu, champagne, scotch, Mandarin orange, Colombian coffee, Bastami rice as well as non-food product, such as handicrafts, pashmina.[4]

Fraud constitutes the forerunner to the protection of a region as an indication of source and then subsequently becomes geographical indication. In 1994, Geographical Indication was introduced by GI in Trade Related Aspects of Intellectual Property Rights (TRIPS) Agreement of the World Trade Organization (WTO). With 160 members of WTO, TRIPs denotes the institutionalization of the international concept leading to possibilities of 9,000 to 10,000 GI worldwide. Outside European Union in 2012, appellation of origins and GI include 1,181 agricultural and food products, and 1,757 wine with sales value of $€ 54,3$ billion. TRIPs Agreement grants exclusive rights to each indication which identifies goods originating from a particular place with particular characteristics and/or quality. However, the agreement provides limited number of protection against fraud on products protected by indication of source. TRIPs Agreement provides the framework and procedure in terms of territorial protection within a state.

In Indonesia, protection of indication of source is governed by Law No. 20 of 2016 article 64 concerning Trademark and Geographical Indications, indication of origin is protected without an obligation to register or to declare as an indication which shown the true origin of goods and/or services to be used in trade.

Within article 64 Law no. 20 of 2016 concerning Trademark and Geographical Indications, it is stated that indication of origin is a mark of origin for the goods and/or services, which does not directly correlated with element of nature. Correlation with element of nature is protected by geographical indications, while the indication of origin is protected by simply naming the origin of a product. Indication of origin can be used as an anticipation of fraud if the protection of geographical indication remains in process of 
registration because protection of geographical indications requires testing and lengthy time of process.

\section{INDICATION OF SOURCE PROTECTION OF IKAT SUMBA}

Goods or products of geographical indications may be in the form of agricultural products, processed products, handicrafts, or other goods which contains the names of region, place, area or other marks indicating the origin of place protected by geographical indications.
a. Agricultural products;
b. Processed products;
c. Handicrafts; and
d. Other goods.

Handicrafts with registered geographical indications are somewhat few even though products with aesthetic value are easily found in Indonesia; for example, besides Sumba, weaving products can also be found in other areas in East Nusa Tenggara, such as in Kampung Tarung Waikabubak, Waingapu with their own characteristics in terms of patterns and color. Those are considered to be potential to be protected by geographical indications.

\section{A. PROTECTION SYSTEM OF NATURAL DYEING OF IKAT SUMBA}

Ikat Sumba is a traditional textile used by society in the island of Sumba since thousands of years ago. It has become part of the customs in Sumba. Ikat Sumba is an important attribute in ceremonial occasion, such as weddings or coronation. Nowadays, Ikat Sumba is worn on daily basis and becomes part of various traditional ceremonies, for example funeral.

The making of Ikat Sumba proceeds through a number of stages: drawing patterns, dyeing, weaving. Generally, natural dye is derived from plants in Sumba. The process of dyeing is carried out on average for 3-4 times and on maximum of 6 times. Blue dye (kawaru) is made from the leaves of true indigo (Indigofera tinctoria). Red dye is made from the roots of Noni (Morinda citrifolia). Black dye is made from mud.

Colors and patterns of Ikat vary in each tribe on the island of Sumba and are manually and traditionally processed. Usually, Ikat Sumba is categorized in three groups in terms of its patterns: figurative representations of human and animals, geometric, and foreign influences, such as Cross, Patola (India), and Dragon (China).
The process of making Ikat in East Sumba uses natural dye made from plants (roots, barks, and leaves) and constitutes non-timber forest products (NTFPs).[5]

The use of natural dye in Indonesia has emerged during the colonialism era, especially for textile dyeing. Until present, natural dye remain used primarily for Ikat textile. Natural dyeing is preferred since it creates distinct characteristics which is hardly possible to be duplicated by synthetic dyeing. It supports Ikat textile to become an exclusive product which attract a lot of people. The process of making Ikat in East Sumba uses ATBM (Manual Loom) which takes longer time and undergoes complicated process; hence, the products are rather high-priced. However, the selection and process of plants used for natural dyeing remain unexplored and undocumented. It is necessary as the basis for the preparation of strategies for preservation and development of the plants in order to support the sustainability of Ikat business of natural dyeing.[6]

Commonly, natural dye is made from plants in Sumba. Blue dye (kawaru) is made from the leaves of true indigo (Indigo tinctoria). Red dye is made from the root of noni (Morinda citrifolia). Black dye is made from mud.

The dyes mostly used for Ikat textile in East Sumba are red, black, and blue. Ingredients in making the dyes are obtained from various parts of plants (leaves, barks, roots, fruits, and seeds). From an interview, it is known that 20 plants are used as natural dyes for Ikat textiles in the district of East Sumba, yet the mostly used ones are of five plants, producing the colors of red, black, and blue. Of those five plants, four of which are forest trees (non-timber forest products), of which parts used are fruits, roots, and barks; meanwhile, the other plant is the shrubs of true indigo (Indigofera tinctoria).

Ikat textile of East Suma uses Indigofera tinctoria as its primary source of blue dye in the process of natural dyeing as well as uses plant roots as the color binder. Weavers in the Eastern part of Indonesia, such as Flores, Sumba, and Sabu Raijua state that they dye the textile using natural dye as a tradition; they also use varied species of Symplocos containing hyperaccumulators of aluminum. It is also reported that people in East and West Sumba remain using natural dye in producing Ikat textile for it plays important roles in determining the quality.[7] 
The process of making Ikat Sumba includes numerous stages: drawing patterns, dyeing, weaving. The process of dyeing is carried out on average for 3-4 times and on maximum of 6 times.

The patterns of Ikat Sumba are categorized into three: the figurative group representing human and animals, the schematic group resembling charts or geometric shapes, and foreign influence group, such as cross, Patola (India), and dragon (China).[8]

Ecosystem greatly affects the supply of natural dye for Ikat Sumba. Savanna with rocky soil overgrown by varied species of plants resistant to drought and marginal land are dominantly found in the island. Various species of trees and shrubs sporadically grown in savanna are used as natural dye for Ikat, such as true indigo (Indigofera tinctoria L.) and noni (Morinda citrifolia L.)

Natural dyeing depends on the geographical conditions in which the textile originates; therefore, such potential needs protection by the intellectual property of geographical indications. In the article by Giovanni Belleti et al., it is stated that:

"Geographical indications, or GIs, identify products that have a specific quality tied to their geographical origin. These origin-based products, or Original Products (OP), are the result of technical, social, and economic interactions, including both the mobilization of locally specific resources such as local know-how and cultural traditions, and the construction of product quality within marketing chains between producers and consumers. Over time, actors involved in these interactions shape the identity of an OP by tying its specific quality attributes to the territory where it is produced, rather than to a single firm, and by bringing it under a geographical name, or a GI, rather than a private trademark. If, thanks to supply, demand, and market conditions, the process of valorizing an OP proves successful, consumers will recognize the geographical name over time, it will be incorporated into a collective reputation. The OP can thus become a "GI product"[9]

The protection of geographical indications of Ikat Sumba of natural dye is categorized as geographical indications. Local government or the community is able to register the geographical indication of Ikat Sumba of natural dye to the office of Directorate General of Intellectual Property, Ministry of Law and Human Rights.

Protection in terms of indication of course can be opted prior to the protection of geographical indication. It constitutes a preventive measure in order to protect Ikat of natural dye originating from the island of Sumba. Protection of indication of origin can also be registered by each region in
NTT, such as East Sumba, Southwest Sumba, and other areas in Sumba.

\section{B. INDICATION OF SOURCE PROTECTION BY LOCAL GOVERNMENT FOR NATURAL DYEING OF IKAT SUMBA}

Geographical indications are protected after being registered through an application which can be submitted by: a. An institution representing a particular community in a certain geographic region. It can be interpreted that an institution can be both a legal entity and non-legal entity. A farmer group or business group can even apply. Submitting an application means that ownership is requested under the name of the institution or community.

b. Local government; geographical indications are protected as long as the reputation, quality, and characteristics of the protected geographical indications remain well-maintained.

Local government and an institution representing a certain community constitute parties who are obliged to protect the indication of source of Ikat Sumba with natural dye. Data recording of weavers and textile producers, categorizing based on the place of origin, and product labeling are preventive means on the protection of source regarding Ikat Sumba with natural dye. It also prevent the possibility of fraud from the competitors which can lead to consumers mislead of the origin product.

\section{ECONOMICAL AND INCOME IMPROVEMENTS OF SMALL AND MEDIUM-SIZED ENTERPRISES IN SUMBA}

Economical improvement in a region with indication of source product can be materialized. Indication of source related to a region or area leverages the emergence of smallsized enterprises. The purpose of indication of source protection is to assist individuals, producers, and craftsmen in either a home-based or group enterprise and to protect the products in order to gain economical profit to the producers.

As a common property, geographical indication is effective in protecting the collectivity of local product 
producers. Geographical indication protection is not unlimited in terms of period. A local product will remain protected as long as both the distinctive characteristics and quality in the protected product remain present, as well. Such protection mechanism brings benefits to producers and consumers. Producers are not burdened with high amount of registration fees, since the registration is collective and does not require constant renewal. Consumer interests are met with the obligation of the producer to maintain the characteristics and quality of the Geographical Indication products.

Indication of source protection by local government or certain community can increase the local economy significantly. The inclusion of indication of source brings acknowledgement to the consumers or community that Ikat with natural dyeing can be found in Sumba. Also, inclusion of indication of source label on the product triggers the consumers to purchase Ikat textile which is originated from Sumba and are not misled to purchase the textile from other area.

\section{CONCLUSION}

This article discusses on the protection of indication of source as a preventive means to avoid fraud as a part of unfair business competition towards Ikat Sumba with natural dyeing. Protection of indication of source is an effort by local government or certain producer community to protect Ikat textile using natural dye. Though protection on geographical indications through registration system takes lengthy time to proceed, it can significantly increase local economy because the consumer will no longer be misled in purchasing the original product.

Ikat textile of natural dye is closely related to the region or area in which the textile is produced. It is due to the fact that natural dye is made from plants growing in the forest or garden nearby. The plants growing in each region of East Nusa Tenggara vary meaning that the selection of plant used for natural dyeing in East Nusa Tenggara is different from one area to another.

The distinctive characteristics of Ikat textile in East Nusa Tenggara are means of improving the economy in the province. The local government as an authority party is in charge of protecting the indication of source and is expected to be able to provide protection for small-sized enterprises as well as to improve local economy in Sumba, East Nusa Tenggara.

\section{REFERENCE}

[1] Mariana Takandjandji, 'TINGKAT PEMANFAATAN TUMBUHAN PENGHASIL WARNA PADA USAHA TENUN IKAT DI KABUPATEN SUMBA TIMUR Utilization Level of Plat Produce Natural Dye at Cloth Woven Business in East Sumba District', 12.3 (2015), $223-37$.
[2] The Paris Convention for Protection of lndustrial Property of 1883 and the 1911 Revision, opened for signature 13 January 1968, art 1, 7, 10, 10bis, 10ter (came into force 26 April or 15 May 1970).

[3] Ibid

[4] Mariana Takandjandji.Op.Cit.

[5] Murniati - and Mariana Takandjandji, 'ANALISIS USAHA TENUN IKAT BERBASIS PEWARNA ALAM DI KABUPATEN SUMBA TIMUR: Kasus Di Kecamatan Kambera Dan Umalulu', Dinamika Kerajinan Dan Batik: Majalah Ilmiah, 33.1 (2016), 6784

<https://doi.org/http://dx.doi.org/10.22322/dkb.v33i1.10 63>.

[6] Mariana Takandjandji.Op.Cit.

[7] Mariana Takandjandji.Op.Cit.

[8] Tenun Ikat memesona dunia, Dwi as Setianingsih, http://travel.kompas.com/read/2013/10/27/1219020/Kain.Sum b a.Memesona.Dunia,

[9] Giovanni Belletti, Andrea Marescotti, and Jean Marc Touzard, 'Geographical Indications, Public Goods, and Sustainable Development: The Roles of Actors' Strategies and Public Policies', World Development, 98 (2015), 45-57 $<$ https://doi.org/10.1016/j.worlddev.2015.05.004>. 